\title{
The MEK inhibitor PD98059 attenuates growth inhibition and death in gallic acid-treated Calu-6 lung cancer cells by preventing glutathione depletion
}

\author{
YONG HWAN HAN ${ }^{1}$, HWA JIN MOON ${ }^{1}$, BO RA YOU ${ }^{1}$, YEON MI YANG ${ }^{2}$, SUNG ZOO KIM ${ }^{1}$, \\ SUHN HEE KIM ${ }^{1}$ and WOO HYUN PARK ${ }^{1}$
}

${ }^{1}$ Department of Physiology, Medical School, Institute for Medical Sciences; ${ }^{2}$ Department of Pediatric Dentistry, School of Dentistry, Chonbuk National University, Jeonju 561-180, Korea

Received December 21, 2009; Accepted March 15, 2010

DOI: $10.3892 / \mathrm{mmr} 00000291$

\begin{abstract}
Gallic acid (GA) is widely distributed in various plants and foods and has various biological effects. In this study, we investigated the effects of mitogen-activated protein kinase (MEK, JNK or p38) inhibitors on GA-induced Calu-6 lung cancer cell death in relation to reactive oxygen species (ROS) and glutathione (GSH) levels. GA inhibited the growth of Calu- 6 cells and induced apoptosis and/or necrosis accompanied by the loss of mitochondrial membrane potential (MMP; $\Delta \Psi_{\mathrm{m}}$ ). ROS levels and the number of GSH-depleted cells were observed to be increased at $24 \mathrm{~h}$. MEK inhibitor suppressed cell growth inhibition, death, MMP $\left(\Delta \Psi_{\mathrm{m}}\right)$ loss and GSH depletion induced by GA, but failed to suppress the increase in ROS levels. JNK inhibitor also somewhat suppressed cell growth inhibition, MMP $\left(\Delta \Psi_{\mathrm{m}}\right)$ loss and GSH depletion induced by GA, and limited the increase in ROS levels. By contrast, p38 inhibitor mildly enhanced GA-induced cell growth inhibition, MMP $\left(\Delta \Psi_{\mathrm{m}}\right)$ loss and the increase in ROS levels. In conclusion, MEK inhibitor suppressed GA-induced cell growth inhibition and death in Calu-6 cells. This was related to the prevention of GSH depletion.
\end{abstract}

Correspondence to: Dr Woo Hyun Park, Department of Physiology, Medical School, Institute for Medical Sciences, Chonbuk National University, Jeonju 561-180, Korea

E-mail: parkwh71@chonbuk.ac.kr

Abbreviations: GA, gallic acid; ROS, reactive oxygen species; MAPK, mitogen-activated protein kinase; MEK, MAP kinase or ERK kinase; ERK, extracellular signal-regulated kinase; JNK, c-Jun N-terminal kinase; SOD, superoxide dismutase; MMP $\left(\Delta \Psi_{\mathrm{m}}\right)$, mitochondrial membrane potential; FBS, fetal bovine serum; FITC, fluorescein isothiocyanate; $\mathrm{H}_{2}$ DCFDA, 2',7'dichlorodihydrofluorescein diacetate; DHE, dihydroethidium; GSH, glutathione; CMFDA, 5-chloromethylfluorescein diacetate; MTT, 3-(4,5-dimethylthiazol-2-yl)-2,5-diphenyltetrazolium bromide; PI, propidium iodide

Key words: gallic acid, apoptosis, cell death, Calu-6, mitogenactivated protein kinase, reactive oxygen species

\section{Introduction}

Gallic acid (GA; 3,4,5-triphydroxyl-benzoic acid) is a polyhydroxylphenolic compound that is widely distributed in various plants, fruits and other foods (1), and is very well absorbed by humans (2). Various biological effects of GA have been reported, including anti-bacterial (3), anti-viral (4) and anti-inflammatory activities (5). The major point of interest in GA is related to its anti-cancer activity, which has been reported in various cancer cells, including prostate (6), lung $(7,8)$, gastric, colon, breast, cervical and esophageal cancer (9). Apoptosis induced by GA is associated with oxidative stress derived from reactive oxygen species (ROS), mitochondrial dysfunction and an increase in intracellular $\mathrm{Ca}^{2+}$ levels $(10,11)$. Controversially, GA has been suggested to have both pro-oxidant and antioxidant properties depending on iron or $\mathrm{H}_{2} \mathrm{O}_{2}$ levels in medium and plasma $(12,13)$.

There are currently three well-known mitogen-activated protein kinases (MAPKs): extracellular signal regulated kinase (ERK1/2), c-Jun N-terminal kinase/stress-activated protein kinase (JNK/SAPK) and p38 kinase (14). Each MAP kinase pathway has relatively different upstream activators and specific substrates (15). Multiple lines of evidence demonstrate that JNK and p38 are strongly activated by ROS or by a mild oxidative shift in the intracellular thiol/disulfide redox state, leading to apoptosis $(16,17)$. ROS are also known to induce ERK phosphorylation and to activate the ERK pathway (18). In most instances, ERK activation has a pro-survival rather than a pro-apoptotic effect (19). Since variations in the level of ROS and differences in the function of MAPKs as influenced by ROS may have opposite effects in even the same type of cells, the relationship between ROS and MAPKs in terms of cell survival or cell death signaling requires further clarification.

Understanding the toxicological mechanisms of GA in cancer cells in relation to ROS and MAPK signaling may aid in the development of anti-cancer agents. However, little is known about the relationship between ROS levels and MAPK signaling in GA-treated cancer cells. We recently observed that GA inhibited the growth of lung cancer cells including Calu-6 lung cells (unpublished data). Therefore, in the present study, we investigated the effects of MAPK inhibitors on cell growth inhibition, cell death, ROS and GSH levels in GA-treated Calu-6 lung cells. 


\section{Materials and methods}

Cell culture. The human pulmonary adenocarcinoma Calu- 6 cell line was obtained from the American Type Culture Collection (ATCC, Manassas, VA) and maintained in a humidified incubator containing $5 \% \mathrm{CO}_{2}$ at $37^{\circ} \mathrm{C}$. Calu- 6 cells were cultured in RPMI-1640 supplemented with $10 \%$ fetal bovine serum (FBS) and $1 \%$ penicillin-streptomycin (Gibco Brl, Grand Island, NY).

Reagents. GA was purchased from the Sigma-Aldrich Chemical Company (St. Louis, MO) and dissolved in ethanol at $200 \mathrm{mM}$ as a stock solution. MEK inhibitor (PD98059), JNK inhibitor (SP600125) and p38 inhibitor (SB203580) were obtained from Calbiochem (San Diego, CA) and dissolved in DMSO at $10 \mathrm{mM}$ as a stock solution. Cells were pre-treated with each MAPK inhibitor for 30 min prior to GA treatment. Based on a previous experiment (20), $10 \mu \mathrm{M}$ of each MAPK inhibitor was used as an optimal dose in this experiment. Ethanol $(0.2 \%)$ and DMSO $(0.3 \%)$ were used as the control vehicle. Stock solutions were wrapped in foil and maintained at $-20^{\circ} \mathrm{C}$.

Cell growth assay. The in vitro growth inhibitory effect of GA on cells was determined by using 3-(4,5-dimethylthiazol2-yl)-2,5-diphenyltetrazolium bromide (MTT) as previously described (21). In brief, $3 \times 10^{4}$ cells per well were seeded in 96-well microtiter plates for MTT assay. After exposure to the indicated dose of GA and/or each MAPK inhibitor for $24 \mathrm{~h}$, $20 \mu \mathrm{l}$ of MTT (Sigma) solution ( $2 \mathrm{mg} / \mathrm{ml}$ in PBS) were added to each well of the 96-well plates. The plates were incubated for an additional $4 \mathrm{~h}$ at $37^{\circ} \mathrm{C}$. Medium in plates was drawn using a pipette and $200 \mu \mathrm{l}$ of DMSO was added to each well to solubilize the formazan crystals. Optical density was measured at $570 \mathrm{~nm}$ using a microplate reader (Spectra MAX 340; Molecular Devices Co. Sunnyvale, CA).

Sub-G1 DNA content analysis. The sub-G1 DNA content of the cells was determined by propidium iodide (PI; Ex/Em $=488 \mathrm{~nm} / 617 \mathrm{~nm}$; Sigma-Aldrich) staining as previously described (22). In brief, $1 \times 10^{6}$ cells in a 60 -mm culture dish (Nunc) were incubated with GA and/or each MAPK inhibitor for $24 \mathrm{~h}$, then washed with PBS and fixed in 70\% ethanol. Subsequently, the cells were washed again with PBS, then incubated with PI $(10 \mu \mathrm{g} / \mathrm{ml})$ with simultaneous RNase treatment at $37^{\circ} \mathrm{C}$ for $30 \mathrm{~min}$. Cell DNA content was measured using a FACStar flow cytometer (Becton Dickinson, San Jose, CA).

Annexin V staining for cell death detection. Apoptosis was determined by staining with Annexin V-fluorescein isothiocyanate (FITC; Ex/Em = $488 \mathrm{~nm} / 519 \mathrm{~nm}$; Pharmingen, San Diego, CA) as previously described (22). In brief, $1 \times 10^{6}$ cells in a 60-mm culture dish (Nunc) were incubated with GA and/ or each MAPK inhibitor for $24 \mathrm{~h}$. Cells were washed twice with cold PBS and then resuspended in $500 \mu \mathrm{l}$ of binding buffer (10 mM HEPES/NaOH, pH 7.4, $140 \mathrm{mM} \mathrm{NaCl}, 2.5 \mathrm{mM}$ $\mathrm{CaCl}_{2}$ ) at a concentration of $1 \times 10^{6} \mathrm{cells} / \mathrm{ml}$. Annexin V-FITC $(5 \mu \mathrm{l})$ was then added to the cells, which were analyzed with a FACStar flow cytometer (Becton Dickinson).

Measurement of MMP $\left(\Delta \Psi_{m}\right)$. MMP $\left(\Delta \Psi_{\mathrm{m}}\right)$ levels were measured using Rhodamine 123 fluorescent dye $(\mathrm{Ex} / \mathrm{Em}=$
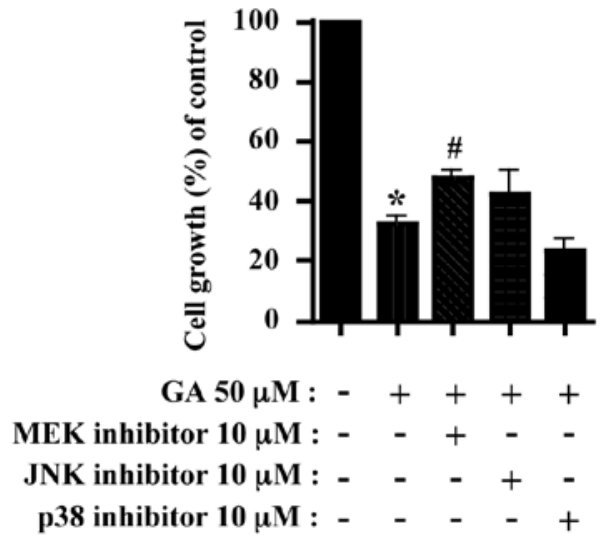

Figure 1. Effect of MAPK inhibitors on cell growth in GA-treated Calu-6 cells. Exponentially growing cells were treated with $50 \mu \mathrm{M}$ GA for $24 \mathrm{~h}$ following a 30-min pre-incubation with $10 \mu \mathrm{M}$ MEK, JNK or p38 inhibitor. Cell growth was assessed using the MTT assay. ${ }^{*} \mathrm{p}<0.05$ compared to the control group. ${ }^{\#} \mathrm{p}<0.05$ compared to cells treated with GA only.

$485 \mathrm{~nm} / 535 \mathrm{~nm}$; Sigma) as previously described (23). In brief, $1 \times 10^{6}$ cells in a $60-\mathrm{mm}$ culture dish (Nunc) were incubated with GA and/or each MAPK inhibitor for $24 \mathrm{~h}$. Cells were washed twice with PBS and incubated with Rhodamine 123 $(0.1 \mu \mathrm{g} / \mathrm{ml})$ at $37^{\circ} \mathrm{C}$ for $30 \mathrm{~min}$. Rhodamine 123 staining intensity was determined by flow cytometry. The absence of Rhodamine 123 staining indicated the loss of $\operatorname{MMP}\left(\Delta \Psi_{\mathrm{m}}\right)$. $\operatorname{MMP}\left(\Delta \Psi_{\mathrm{m}}\right)$ levels in cells excepting cells with $\operatorname{MMP}\left(\Delta \Psi_{\mathrm{m}}\right)$ loss were expressed as the mean fluorescence intensity (MFI), calculated using CellQuest software.

Detection of intracellular $\mathrm{ROS}$ and $\mathrm{O}_{2}^{*}$ levels. Intracellular ROS levels, including $\mathrm{H}_{2} \mathrm{O}_{2}$, $\mathrm{OH}$ and $\mathrm{ONOO}$; were detected by means of an oxidation-sensitive fluorescent probe dye, 2',7'-dichlorodihydrofluorescein diacetate $\left(\mathrm{H}_{2} \mathrm{DCFDA}\right.$; Ex/ $\mathrm{Em}=495 \mathrm{~nm} / 529 \mathrm{~nm}$; Invitrogen Molecular Probes, Eugene, OR) (24). $\mathrm{H}_{2}$ DCFDA is poorly selective for $\mathrm{O}_{2}{ }^{\circ}$. By contrast, dihydroethidium (DHE; Ex/Em = $518 \mathrm{~nm} / 605 \mathrm{~nm}$; Invitrogen Molecular Probes) is highly selective for $\mathrm{O}_{2}{ }^{-}$among ROS. In brief, $1 \times 10^{6}$ cells in a $60-\mathrm{mm}$ culture dish (Nunc) were incubated with GA and/or each MAPK inhibitor for $24 \mathrm{~h}$. Cells were then washed with PBS and incubated with $20 \mu \mathrm{M}$ $\mathrm{H}_{2}$ DCFDA or DHE at $37^{\circ} \mathrm{C}$ for $30 \mathrm{~min}$. DCF and DHE fluorescence was detected using a FACStar flow cytometer (Becton Dickinson). ROS and $\mathrm{O}_{2}^{-}$- levels were expressed as the MFI, calculated using CellQuest software.

Detection of intracellular glutathione. Cellular GSH levels were analyzed using 5-chloromethylfluorescein diacetate $(\mathrm{CMFDA} ; \mathrm{Ex} / \mathrm{Em}=522 \mathrm{~nm} / 595 \mathrm{~nm}$; Invitrogen Molecular Probes) as previously described (24). In brief, $1 \times 10^{6}$ cells in a 60-mm culture dish (Nunc) were incubated with GA and/or each MAPK inhibitor for $24 \mathrm{~h}$. Cells were then washed with PBS and incubated with $5 \mu \mathrm{M}$ CMFDA at $37^{\circ} \mathrm{C}$ for $30 \mathrm{~min}$. CMF fluorescence intensity was determined using a FACStar flow cytometer (Becton Dickinson). Negative CMF staining (GSH-depleted) cells were expressed as the percentage of (-) CMF cells. CMF levels in cells excepting GSH-depleted cells were expressed as the MFI, calculated using CellQuest software. 
A

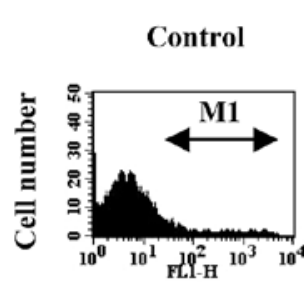

Annexin V-FITC
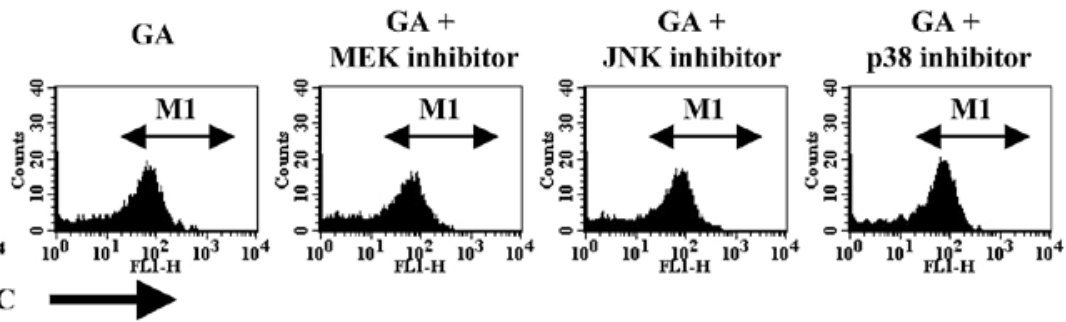

B
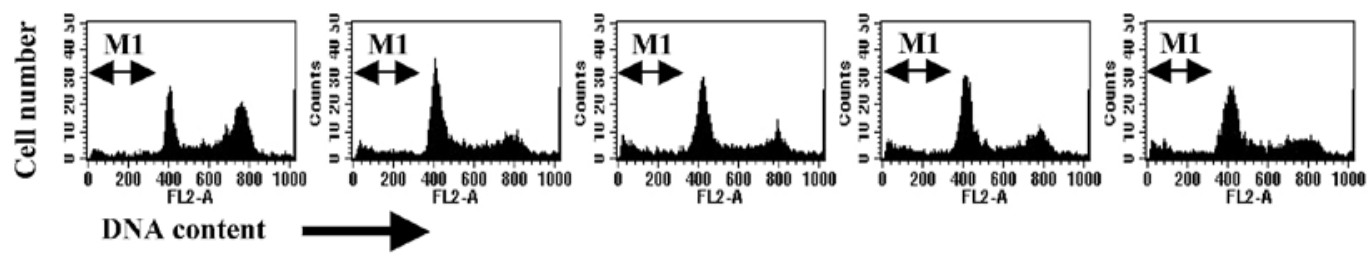

C

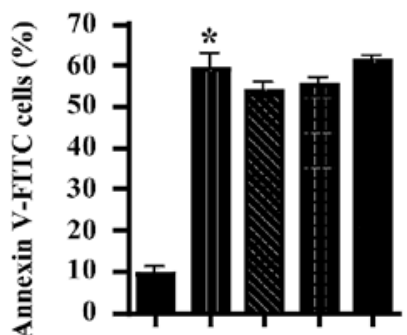

D

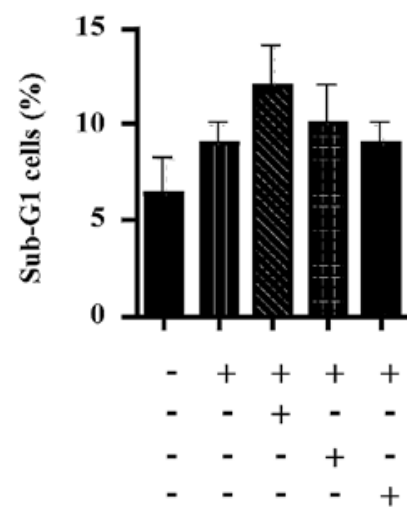

Figure 2. Effect of MAPK inhibitors on cell death in GA-treated Calu- 6 cells. Exponentially growing cells were treated with $50 \mu \mathrm{M}$ GA for $24 \mathrm{~h}$ following a 30-min pre-incubation with $10 \mu \mathrm{M}$ MEK, JNK or p38 inhibitor. Histograms are representative examples of (A) Annexin V staining and (B) sub-G1 DNA content, analyzed with a FACStar flow cytometer. M1 region (A), Annexin V-stained cells. M1 region (B), sub-G1 cells. Graphs represent the percentage of (C) Annexin V-stained cells (M1 region, A) and (D) sub-G1 cells (M1 region, B). "p<0.05 compared to the control group.

Statistical analysis. The results are representative of at least three independent experiments (mean $\pm \mathrm{SD}$ ). The data were analyzed using Instat software (GraphPad Prism4, San Diego, CA). One-way analysis of variance (ANOVA) with post hoc analysis using Tukey's multiple comparison test was used to compare the parametric data. Statistical significance was defined as $\mathrm{p}<0.03$.

\section{Results}

Effect of MAPK inhibitors on cell growth in GA-treated Calu-6 cells. We first examined the effect of MAPK inhibitors on the growth of GA-treated Calu- 6 cells. Calu- 6 cell growth was dose-dependently diminished with an $\mathrm{IC}_{50}$ of $\sim 30 \mu \mathrm{M}$ GA (data not shown). The $50 \mu \mathrm{M}$ of GA used in this study was shown to suppress the growth of Calu-6 cells by $\sim 67 \%$ (Fig. 1). MEK inhibitor significantly suppressed and JNK inhibitor slightly suppressed the growth inhibition induced by GA in Calu- 6 cells (Fig. 1). Conversely, p38 inhibitor mildly enhanced GA-induced growth inhibition (Fig. 1). MAPK inhibitors alone slightly inhibited the growth of Calu-6 control cells (data not shown).

Effect of MAPK inhibitors on cell death and MMP $\left(\Delta \Psi_{m}\right)$ in GA-treated Calu- 6 cells. GA induced cell death in Calu-6 cells at $24 \mathrm{~h}$, as evidenced by trypan blue staining (data not shown) and Annexin V staining (Fig. 2A and C). However,
GA did not increase the number of sub-G1 cells (Fig. 2B and D). Therefore, it would appear that GA inhibited the growth of Calu- 6 cells via apoptosis and/or necrosis. None of the MAPK inhibitors significantly affected the number of Annexin $\mathrm{V}$ stained or sub-G1 cells (Fig. 2), though the MEK and JNK inhibitors did slightly decrease the percentage of Annexin $\mathrm{V}$ stained cells (Fig. 2A and C). None of the MAPK inhibitors alone affected the number of Annexin $\mathrm{V}$ stained or sub-G1 cells in the Calu- 6 control cells (data not shown).

GA also significantly induced the loss of MMP $\left(\Delta \Psi_{\mathrm{m}}\right)$ at $24 \mathrm{~h}$ (Fig. 3A and B). The MEK and JNK inhibitors slightly prevented the loss of MMP $\left(\Delta \Psi_{\mathrm{m}}\right)$ in the GA-treated Calu-6 cells, whereas p38 inhibitor mildly increased the loss of MMP $\left(\Delta \Psi_{\mathrm{m}}\right)$ (Fig. 3A and B). In relation to basal MMP $\left(\Delta \Psi_{\mathrm{m}}\right)$ levels, GA reduced MMP $\left(\Delta \Psi_{\mathrm{m}}\right)$ levels in the Calu-6 cells (Fig. 3A and $\mathrm{C})$. None of the inhibitors significantly altered $\operatorname{MMP}\left(\Delta \Psi_{\mathrm{m}}\right)$ levels in the GA-treated Calu-6 cells (Fig. 3A and C). However, the MEK and p38 inhibitors alone reduced the basal levels of $\operatorname{MMP}\left(\Delta \Psi_{\mathrm{m}}\right)$ in the Calu- 6 control cells (data not shown).

Effect of MAPK inhibitors on ROS and GSH levels in GA-treated Calu-6 cells. Next, we determined whether the levels of intracellular ROS and GSH in the GA-treated Calu-6 cells were affected by each MAPK inhibitor. ROS (DCF) levels such as $\mathrm{H}_{2} \mathrm{O}_{2}$ were increased in the GA-treated Calu- 6 cells (Fig. 4A and C). All the MAPK inhibitors appeared to increase 
A

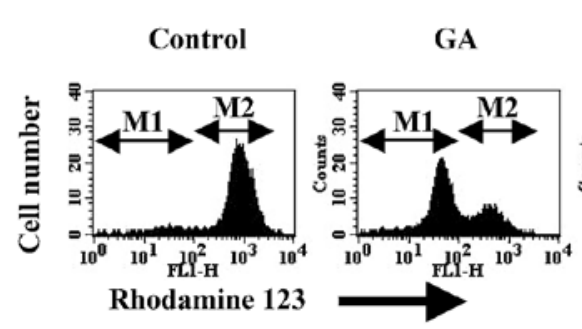

GA +

GA +
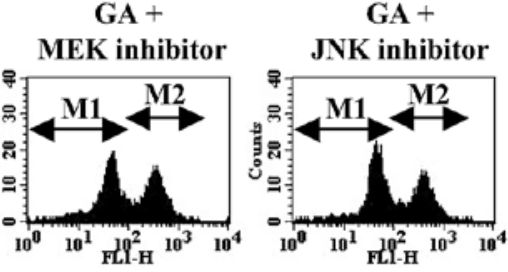

GA +

p38 inhibitor

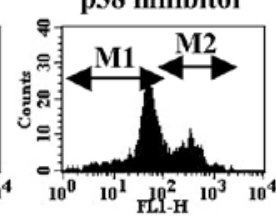

B

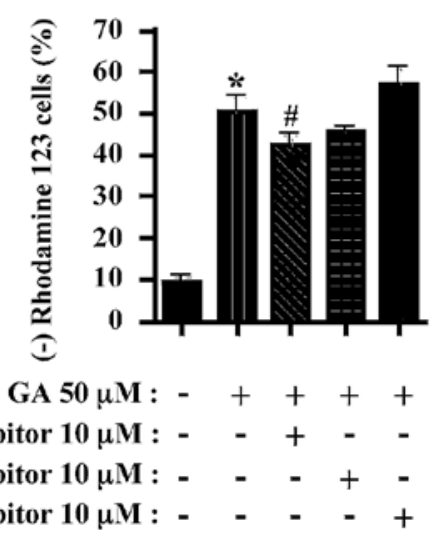

C

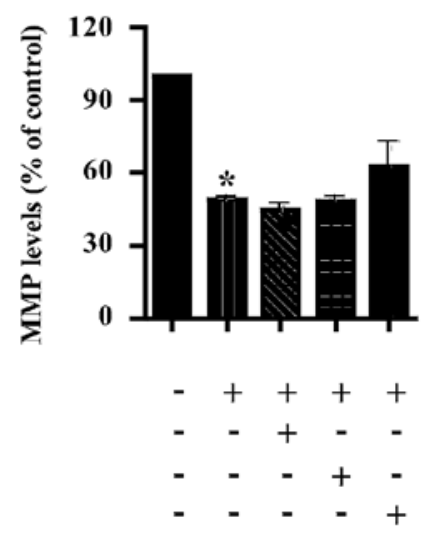

Figure 3. Effect of MAPK inhibitors on MMP $\left(\Delta \Psi_{\mathrm{m}}\right)$ in GA-treated Calu-6 cells. Exponentially growing cells were treated with $50 \mu \mathrm{M}$ GA for $24 \mathrm{~h}$ following a 30-min pre-incubation with $10 \mu \mathrm{M}$ MEK, JNK or p38 inhibitor. (A) Histograms are representative examples of MMP $\left(\Delta \Psi_{\mathrm{m}}\right)$ expression. M1 region, Rhodamine 123-negative [MMP $\left(\Delta \Psi_{\mathrm{m}}\right)$ loss] cells. M2 region, cells not including Rhodamine 123-negative [MMP $\left(\Delta \Psi_{\mathrm{m}}\right)$ loss] cells. Graphs represent the percentage of (B) Rhodamine 123-negative [MMP $\left(\Delta \Psi_{\mathrm{m}}\right)$ loss] cells (M1 region, A), and (C) MMP $\left(\Delta \Psi_{\mathrm{m}}\right)$ levels (M2 region, A). ${ }^{*} \mathrm{p}<0.05$ compared to the control group. ${ }^{\#} \mathrm{p}<0.05$ compared to cells treated with GA only.

ROS levels in the GA-treated Calu-6 cells. This increase was significant with p38 inhibitor (Fig. 4A and C). The JNK and p38 inhibitors also increased basal ROS levels in Calu-6 control cells (data not shown). Red fluorescence derived from DHE reflecting intracellular $\mathrm{O}_{2}^{-*}$ levels was also increased in the Calu- 6 cells (Fig. 4B and D). However, none of the MAPK inhibitors had an effect on $\mathrm{O}_{2}^{-}$levels in the GA-treated Calu-6 cells (Fig. 4B and D) or Calu-6 control cells (data not shown).

GA treatment increased the number of GSH-depleted cells in the Calu-6 cells (Fig. 5A and B). This increase was significant with MEK inhibitor (Fig. 5A and B). GA also decreased the GSH level in the Calu-6 cells (Fig. 5A and C). The MEK and JNK inhibitors slightly increased the GSH level in the GA-treated Calu-6 cells (Fig. 5A and C). The MEK and JNK inhibitors alone also increased the basal GSH level in the Calu-6 control cells (data not shown).

\section{Discussion}

ERK activation has a pro-survival rather than a pro-apoptotic effect (19). MEK inhibitor, which presumably decreased ERK activity, slightly suppressed the growth inhibition and death induced by GA. This indirectly suggests that the inhibition of ERK signaling by MEK inhibitor plays a pro-survival role in GA-treated Calu-6 cells. Multiple lines of evidence demonstrate that JNK or p38 signaling is related to cell death $(16,17)$. Indeed, GA was shown to induce PC12 rat phenochromocytoma cell death through the activation of JNK, and JNK inhibitor protected PC12 cells against GA-induced cell death (25). In the present study, JNK inhibitor mildly decreased the growth inhibition and death induced by GA, implying that JNK signaling was involved in Calu- 6 cell death. It has been reported that p38 inhibitor prevents anisomycin-induced macrophage death (26), and we reported that $\mathrm{p} 38$ inhibitor suppressed the death of pyrogallol-induced calf pulmonary artery endothelial cells (20). However, in the current study, p38 inhibitor slightly intensified the growth inhibition induced by GA, and did not significantly affect GA-treated Calu- 6 cell death, indirectly suggesting that p38 signaling is involved in Calu- 6 cell growth, not death. Additionally, p38 inhibitor was shown to enhance cell growth inhibition and cell death in Calu-6 cells via Antimycin A (27). Therefore, the anti- or pro-apoptotic effect of p38 inhibitor depends on the cell types or on the co-administered agents.

Cell death induced by GA has been associated with mitochondrial dysfunction (10). Corroborating this finding, in the present study GA induced the loss of MMP $\left(\Delta \Psi_{\mathrm{m}}\right)$ in Calu-6 cells. While the MEK and JNK inhibitors slightly prevented MMP $\left(\Delta \Psi_{\mathrm{m}}\right)$ loss in the GA-treated Calu-6 cells, p38 inhibitors intensified the degree of MMP $\left(\Delta \Psi_{\mathrm{m}}\right)$ loss. Therefore, the cell death induced by GA and/or the MAPK inhibitors appears to be closely correlated with the loss of $\operatorname{MMP}\left(\Delta \Psi_{\mathrm{m}}\right)$. Furthermore, GA reduced MMP $\left(\Delta \Psi_{\mathrm{m}}\right)$ levels in Calu-6 cells. None of MAPK inhibitors affected MMP $\left(\Delta \Psi_{\mathrm{m}}\right)$ levels in the GA-treated cells. However, the MEK and p38 inhibitors reduced the basal MMP $\left(\Delta \Psi_{\mathrm{m}}\right)$ level in Calu-6 control cells. Therefore, basal MEK or p38 signaling in Calu- 6 control cells may control the maintenance of $\operatorname{MMP}\left(\Delta \Psi_{\mathrm{m}}\right)$. Increasing evidence suggests that apoptosis induced by GA is associated with oxidative stress derived from ROS $(11,28)$. Similarly, ROS levels including $\mathrm{O}_{2}^{-}$were significantly increased in GA-treated Calu- 6 cells. The suppression of GA-induced cell death by the MEK and JNK inhibitors as well as MMP $\left(\Delta \Psi_{\mathrm{m}}\right)$ loss slightly increased ROS (DCF) levels, but did not affect the $\mathrm{O}_{2}{ }^{-}$level. p38 inhibitor significantly increased ROS (DCF) 
A

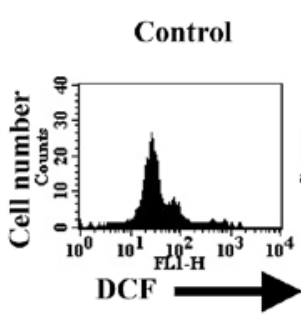

GA

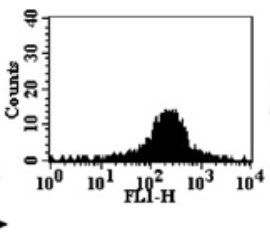

B
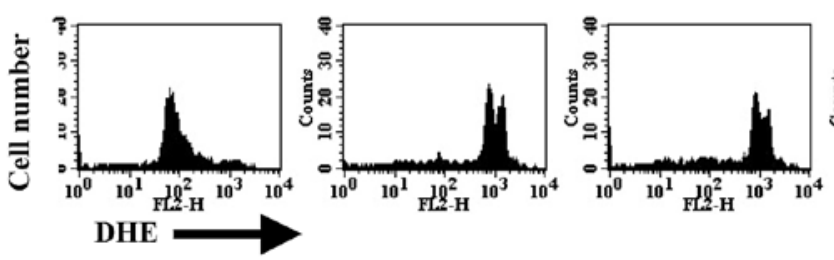

GA +

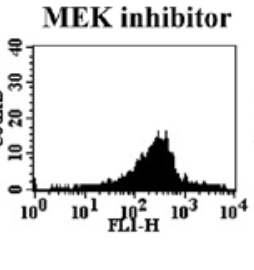

GA +

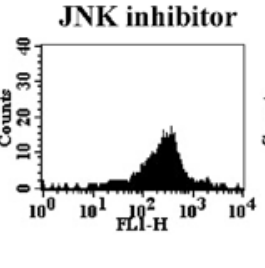

GA + p38 inhibitor

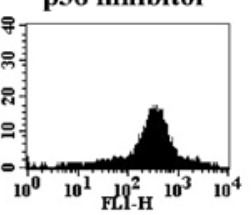

C

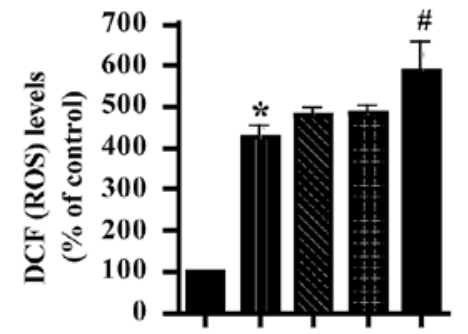

GA $50 \mu \mathrm{M}:-+++$

MEK inhibitor $10 \mu \mathrm{M}$ : - - $+-\quad-$

JNK inhibitor $10 \mu \mathrm{M}$ : - - - + -

p38 inhibitor $10 \mu \mathrm{M}$ : - - - - +
D

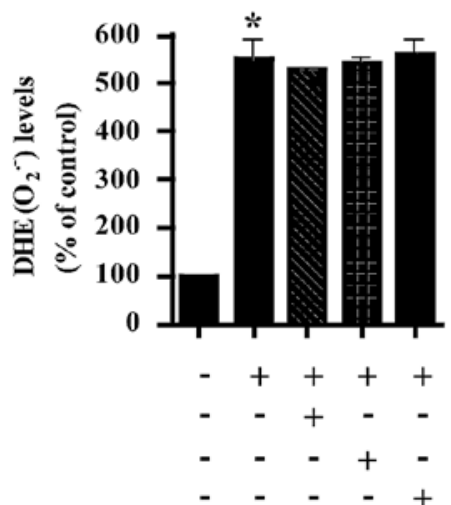

Figure 4. Effect of MAPK inhibitors on ROS levels in GA-treated Calu-6 cells. Exponentially growing cells were treated with $50 \mu \mathrm{M}$ GA for $24 \mathrm{~h}$ following a 30-min pre-incubation with $10 \mu \mathrm{M}$ MEK, JNK or p38 inhibitor. Histograms are representative examples of (A) DCF and (B) DHE levels analyzed with a FACStar flow cytometer. Graphs represent the percentage of (C) DCF (ROS) levels and (D) DHE $\left(\mathrm{O}_{2}^{*}\right)$ levels compared to GA-untreated control cells. ${ }^{*} \mathrm{p}<0.05$ compared to the control group. ${ }^{*} \mathrm{p}<0.05$ compared to cells treated with GA only.

A

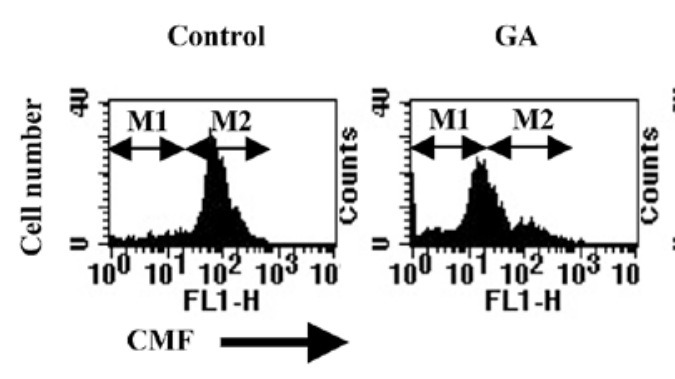

B

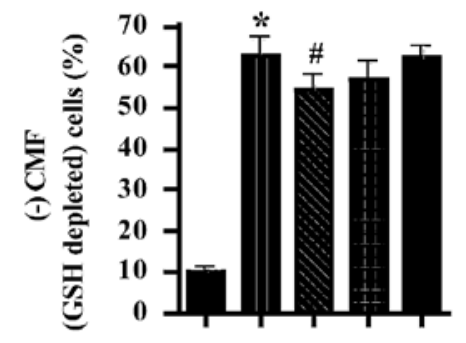

GA $50 \mu \mathrm{M}:-+++$

MEK inhibitor $10 \mu \mathrm{M}:-\quad+--$

JNK inhibitor $10 \mu \mathrm{M}$ : - - - - +
GA + MEK inhibitor JNK inhibitor

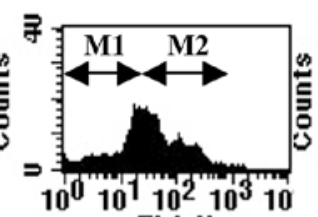

FL1-H

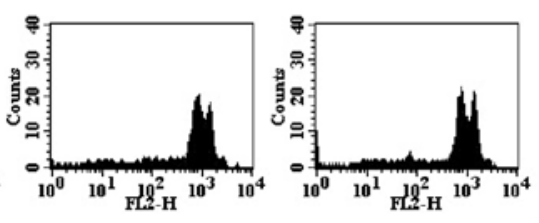

\section{(1)}


levels but not the $\mathrm{O}_{2}^{-}{ }^{-}$level in GA-treated cells. Both the JNK and p38 inhibitor increased ROS levels without affecting cell death in Calu- 6 control cells. These data suggest that the changes in ROS levels by MAPK inhibitors in GA-treated Calu-6 cells are not closely related to cell death.

GSH is a main non-protein antioxidant in cells. It is capable of eliminating the $\mathrm{O}_{2}{ }^{--}$and provides electrons for enzymes such as GSH peroxidase, which reduce $\mathrm{H}_{2} \mathrm{O}_{2}$ to $\mathrm{H}_{2} \mathrm{O}$. It has been reported that intracellular GSH content has a marked effect on anticancer drug-induced apoptosis, indicating that apoptotic effects are inversely related to GSH levels $(29,30)$. Likewise, GA increased the number of GSH-depleted cells in the Calu- 6 cells, while MEK inhibitor decreased the number of GSH-depleted cells in the GA-treated Calu- 6 cells. These results may be related to the results regarding Annexin $\mathrm{V}$ and MMP $\left(\Delta \Psi_{\mathrm{m}}\right)$. The MEK and JNK inhibitors slightly increased the CMF (GSH) level reduced by GA, and significantly increased GSH levels in Calu- 6 control cells. The basal activity of MEK and JNK in Calu- 6 cells therefore appears to influence the intracellular GSH level.

In conclusion, MEK inhibitor suppressed GA-induced growth inhibition and death in Calu- 6 cells. This was related to the prevention of GSH depletion rather than to changes in the level of ROS.

\section{Acknowledgements}

This study was supported by a grant from the Korea Healthcare Technology R\&D Project, Ministry for Health, Welfare and Family Affairs, Republic of Korea (A084194), and a grant from the Korean Ministry of Education, Science and Technology (Regional Core Research Program/Centers for Healthcare Technology Development).

\section{References}

1. Niemetz R and Gross GG: Enzymology of gallotannin and ellagitannin biosynthesis. Phytochemistry 66: 2001-2011, 2005.

2. Shahrzad S, Aoyagi K, Winter A, Koyama A and Bitsch I: Pharmacokinetics of gallic acid and its relative bioavailability from tea in healthy humans. J Nutr 131: 1207-1210, 2001.

3. Kang MS, Oh JS, Kang IC, Hong SJ and Choi CH: Inhibitory effect of methyl gallate and gallic acid on oral bacteria. J Microbiol 46: 744-750, 2008.

4. Kratz JM, Andrighetti-Frohner CR, Leal PC, Nunes RJ, Yunes RA, Trybala E, Bergstrom T, Barardi CR and Simoes CM: Evaluation of anti-HSV-2 activity of gallic acid and pentyl gallate. Biol Pharm Bull 31: 903-907, 2008.

5. Kim SH, Jun CD, Suk K, Choi BJ, Lim H, Park S, Lee SH, Shin HY, Kim DK and Shin TY: Gallic acid inhibits histamine release and pro-inflammatory cytokine production in mast cells. Toxicol Sci 91: 123-131, 2006.

6. Kaur M, Velmurugan B, Rajamanickam S, Agarwal R and Agarwal C: Gallic acid, an active constituent of grape seed extract, exhibits anti-proliferative, pro-apoptotic and antitumorigenic effects against prostate carcinoma xenograft growth in nude mice. Pharm Res 26: 2133-2140, 2009.

7. Kawada M, Ohno Y, Ri Y, et al: Anti-tumor effect of gallic acid on LL-2 lung cancer cells transplanted in mice. Anticancer Drugs 12: 847-852, 2001.

8. Ohno Y, Fukuda K, Takemura G, et al: Induction of apoptosis by gallic acid in lung cancer cells. Anticancer Drugs 10: 845-851, 1999.

9. Faried A, Kurnia D, Faried LS, Usman N, Miyazaki T, Kato H and Kuwano H: Anticancer effects of gallic acid isolated from Indonesian herbal medicine, Phaleria macrocarpa (Scheff.) Boerl, on human cancer cell lines. Int J Oncol 30: 605-613, 2007.
10. Chen HM, Wu YC, Chia YC, Chang FR, Hsu HK, Hsieh YC, Chen CC and Yuan SS: Gallic acid, a major component of Toona sinensis leaf extracts, contains a ROS-mediated anti-cancer activity in human prostate cancer cells. Cancer Lett 286: 161-171, 2009.

11. Inoue M, Sakaguchi N, Isuzugawa K, Tani H and Ogihara Y: Role of reactive oxygen species in gallic acid-induced apoptosis. Biol Pharm Bull 23: 1153-1157, 2000.

12. Strlic M, Radovic T, Kolar J and Pihlar B: Anti- and prooxidative properties of gallic acid in fenton-type systems. J Agric Food Chem 50: 6313-6317, 2002.

13. Sakagami $\mathrm{H}$ and Satoh K: Prooxidant action of two antioxidants: ascorbic acid and gallic acid. Anticancer Res 17: 221-224, 1997.

14. Genestra M: Oxyl radicals, redox-sensitive signalling cascades and antioxidants. Cell Signal 19: 1807-1819, 2007.

15. Kusuhara M, Takahashi E, Peterson TE, Abe J, Ishida M, Han J, Ulevitch R and Berk BC: p38 Kinase is a negative regulator of angiotensin II signal transduction in vascular smooth muscle cells: effects on $\mathrm{Na}^{+} / \mathrm{H}^{+}$exchange and ERK1/2. Circ Res 83: 824-831, 1998.

16. Hsin YH, Chen CF, Huang S, Shih TS, Lai PS and Chueh PJ: The apoptotic effect of nanosilver is mediated by a ROS- and JNK-dependent mechanism involving the mitochondrial pathway in NIH3T3 cells. Toxicol Lett 179: 130-139, 2008.

17. Mao X, Yu CR, Li WH and Li WX: Induction of apoptosis by shikonin through a ROS/JNK-mediated process in Bcr/ Abl-positive chronic myelogenous leukemia (CML) cells. Cell Res 18: 879-888, 2008.

18. Guyton KZ, Liu Y, Gorospe M, Xu Q and Holbrook NJ: Activation of mitogen-activated protein kinase by $\mathrm{H} 2 \mathrm{O} 2$. Role in cell survival following oxidant injury. J Biol Chem 271: 4138-4142, 1996.

19. Henson ES and Gibson SB: Surviving cell death through epidermal growth factor (EGF) signal transduction pathways: implications for cancer therapy. Cell Signal 18: 2089-2097, 2006.

20. Han YH, Moon HJ, You BR, Kim SZ, Kim SH and Park WH: JNK and p38 inhibitors increase and decrease apoptosis, respectively, in pyrogallol-treated calf pulmonary arterial endothelial cells. Int J Mol Med 24: 717-722, 2009.

21. Park WH, Seol JG, Kim ES, Hyun JM, Jung CW, Lee CC, Kim BK and Lee YY: Arsenic trioxide-mediated growth inhibition in MC/CAR myeloma cells via cell cycle arrest in association with induction of cyclin-dependent kinase inhibitor, p21, and apoptosis. Cancer Res 60: 3065-3071, 2000.

22. Han YH, Kim SZ, Kim SH and Park WH: Apoptosis in pyrogallol-treated Calu- 6 cells is correlated with the changes of intracellular GSH levels rather than ROS levels. Lung Cancer 59: 301-314, 2008.

23. Han YH, Kim SZ, Kim SH and Park WH: Arsenic trioxide inhibits growth of As4.1 juxtaglomerular cells via cell cycle arrest and caspase-independent apoptosis. Am J Physiol Renal Physiol 293: F511-F520, 2007.

24. Han YH, Kim SH, Kim SZ and Park WH: Caspase inhibitor decreases apoptosis in pyrogallol-treated lung cancer Calu-6 cells via the prevention of GSH depletion. Int $\mathrm{J}$ Oncol 33: 1099-1105, 2008.

25. Kang MK, Kang NJ, Jang YJ, Lee KW and Lee HJ: Gallic acid induces neuronal cell death through activation of c-Jun $\mathrm{N}$-terminal kinase and downregulation of Bcl-2. Ann NY Acad Sci 1171: 514-520, 2009

26. Croons V, Martinet W, Herman AG, Timmermans JP and De Meyer GR: The protein synthesis inhibitor anisomycin induces macrophage apoptosis in rabbit atherosclerotic plaques through p38 mitogen-activated protein kinase. J Pharmacol Exp Ther 329: 856-864, 2009.

27. Han YH and Park WH: The effects of MAPK inhibitors on antimycin A-treated Calu-6 lung cancer cells in relation to cell growth, reactive oxygen species, and glutathione. Mol Cell Biochem 333: 211-219, 2010.

28. Serrano A, Palacios C, Roy G, Cespon C, Villar ML, Nocito M and Gonzalez-Porque P: Derivatives of gallic acid induce apoptosis in tumoral cell lines and inhibit lymphocyte proliferation. Arch Biochem Biophys 350: 49-54, 1998.

29. Poot M, Teubert H, Rabinovitch PS and Kavanagh TJ: De novo synthesis of glutathione is required for both entry into and progression through the cell cycle. J Cell Physiol 163: 555-560, 1995.

30. Schnelldorfer T, Gansauge S, Gansauge F, Schlosser S, Beger HG and Nussler AK: Glutathione depletion causes cell growth inhibition and enhanced apoptosis in pancreatic cancer cells. Cancer 89: 1440-1447, 2000. 